\section{Patent on PCR enzymes may re-ignite old controversy}

London. Controversy over the patent rights to Taq polymerase, one of the basic thermostable enzymes used in the polymerase chain reaction (PCR) process, is likely to resurface following a decision by the European Patent Office (EPO) to grant a broad-ranging patent to the Swiss pharmaceutical company Hoffman-La Roche.

The patent will cover all thermostable polymerases with a molecular weight between 86,000 and 90,000 . In practice, this means that Hoffman-La Roche - which paid the US biotechnology company Cetus Corporation $\$ 300$ million for the rights to both Taq and PCR in 1991 - will be in a position to demand royalties from the manufacturers of all such enzymes, regardless of whether they are officially used for PCR.

Some companies such as Stratagene, the manufacturers of the enzyme Pfu (which will be covered by the patent), have already agreed to enter licensing deals with Hoffman-La Roche, which is expected to receive up to 20 per cent of the list price of the enzymes. According to Hoffman-La Roche, negotiations with other manufacturers are under way.

But, given the breadth of the claim - the US patent, issued in January 1990, covers only Taq polymerase, and is restricted to its use in PCR - as well as the high financial stakes involved in a technology that has become a staple tool of most molecular biology research, at least one company, Promega Corporation of Madison, Wisconsin, is already planning to contest the patent.

Promega is currently being sued by Roche in the United States for breaching a licence agreement to sell Taq for non-PCR purposes, and is in turn challenging Roche's US patent on Taq, primarily on the grounds that the enzyme had previously been purified by Russian scientists (see Nature 364, 2; 1993).

Other companies are being more cautious. Ira Schildkraut, research director of New England Biolabs, whose wide-selling products VENT and Deep VENT would also be covered by Roche's new patent, merely says that the company is keeping "a close eye" on the situation.

Thermostable polymerases are valuable because they can be used continuously through successive heating cycles used to amplify a sequence of nucleotides in PCR. The EPO initially objected to the Roche application on the grounds that the Russian researchers had published details of a similar thermostable enzyme extracted from the same organism, the bacterium Thermus aquaticus. Roche argued that the enzyme purified by Cetus had a considerably greater accuracy in reproducing nucleotide sequences than the Russian enzyme. This claim appears to have been sufficient to persuade the EPO of the genuine novelty of the Cetus discovery.

News of the preliminary decision was passed to the company by the EPO patent examiner in August. The patent is due to take effect early in the New Year, permitting Roche to take out legal proceedings against those they consider to be infringing it.

Roche officials say they intend to pursue an "active licensing policy" for thermostable enzymes such as Taq "in an effort to make the PCR technology as widely available as possible". The forthcoming patent, they say "will put Roche in a position to continue to actively protect its own interests, as well as those of its licensees". In practice, this is likely to mean that Roche will now increase its efforts to negotiate licensing deals (based on royalty payments) with all other manufacturers of thermostable polymerases.

In theory, the company could also take action against scientists in research laboratories who produce their own Taq. But the company says that is unlikely. "It is not our strategy to resolve disputes at the level of researchers," says the company's PCR licensing manager, Agnieszka JunoszaJankowski.

Many research organizations that use large quantities of Taq say that, although concerned at the increased costs that will inevitably follow the granting of the patent, they intend to pay up because Roche is legally entitled to claim such royalties.

But some scientists point out that Thermus aquaticus is a naturally occurring organism, and others fear that the breadth of the patent might discourage the efforts of other research groups to develop more efficient thermostable enzymes.

Such arguments are likely to be repeated in court if the legal challenge materializes. Although two challenges to the patent application on behalf of unnamed companies have been rejected by the EPO, some (such as Promega) feel that the battle is far from lost - and promise to produce fresh arguments against the patent.

Roche says it is confident it can defend the patent, both in the United States and, if necessary, in Europe. It points out that, in issuing their initial patents, both the US patent office and the EPO have already rejected claims that the Russian scientists got there first.

But others point out that, just because an argument against a patent is rejected by one patent examiner, it does not mean that this argument cannot be used again in a legal challenge to the patent. "It will be interesting to see how this one develops," says one patent attorney who has been closely involved in the issue.

\section{Insurance company to back out of some climate-linked risks}

Munich. Munich Re, the world's largest reinsurance company, has called on governments to meet their commitments to stabilize greenhouse gas emissions in line with the world climate convention, signed in Rio de Janeiro in 1992, because of threats from the impact of climate change.

A company spokesman, WolfOtto Bauer, said last week that the company is "convinced that the trend towards more frequent and more severe natural disasters will continue in the future", and that it intends to reduce some of its high-risk activities in areas related to climate change.

Both statements reflect growing concern among insurance companies that global warming may be responsible for a recent sharp increase in insurance claims resulting from natural disasters (see chart), which have resulted in several bankruptcies in the industry.

They come shortly after the publication of an independent report on the long-term financial risks of climate change to the oil

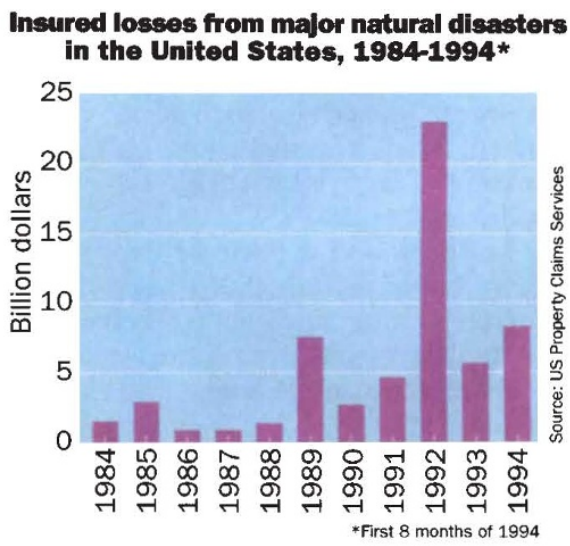

and gas industries commissioned by Greenpeace from the independent Delphi Group of financial consultants.

The report was written by Mark Mansley, former chief analyst with Chase Investment Bank, and is the first study of the impact of climate change on capital markets. It concludes that investors should avoid putting too much money into oil and gas companies because measures to curb carbon-dioxide emissions, which it predicts will be introduced within the decade, will turn such businesses into poor investments.

In addition to Munich $\mathrm{Re}$, a number of other major insurance and reinsurance companies are also becoming involved in the global warming debate. But they are not yet committing themselves to specific policy changes, despite pressure from environmental groups to take more direct steps to help shift energy policy away from fossil fuels.

"It has been bewildering to me to find 